\title{
Biological Denitrification of High Nitrate Processing Wastewaters from Explosives Production Plant
}

\author{
Pawel Cyplik • Roman Marecik • \\ Agnieszka Piotrowska-Cyplik • Anna Olejnik • \\ Agnieszka Drożdżyńska • Lukasz Chrzanowski
}

Received: 14 May 2011 / Accepted: 28 September 2011 / Published online: 11 October 2011

(C) The Author(s) 2011. This article is published with open access at Springerlink.com

\begin{abstract}
Wastewater samples originating from an explosives production plant $\left(3,000 \mathrm{mg} \mathrm{N}^{-1}\right.$ nitrate, $4.8 \mathrm{mg} \mathrm{l}^{-1}$ nitroglycerin, $1.9 \mathrm{mg}^{-1}$ nitroglycol and $1,200 \mathrm{mg}^{-1}$ chemical oxygen demand) were subjected to biological purification. An attempt to completely remove nitrate and to decrease the chemical oxygen demand was carried out under anaerobic conditions. A soil isolated microbial consortium capable of biodegrading various organic compounds and reduce nitrate to atmospheric nitrogen under anaerobic conditions was used. Complete removal of nitrates with simultaneous elimination of nitroglycerin and ethylene glycol dinitrate (nitroglycol) was achieved as a result of the conducted
\end{abstract}

P. Cyplik $(\bowtie) \cdot$ R. Marecik $\cdot$ A. Olejnik · A. Drożdżyńska Department of Biotechnology and Food Microbiology, Poznań University of Life Sciences,

Wojska Polskiego 48,

60-627 Poznań, Poland

e-mail: pcyplik@wp.pl

A. Piotrowska-Cyplik

Institute of Food Technology of Plant Origin,

Poznań University of Life Sciences,

Wojska Polskiego 31,

60-624 Poznań, Poland

Ł. Chrzanowski

Institute of Chemical Technology and Engineering,

Poznań University of Technology,

Pl. M. Skłodowskiej-Curie 2,

60-965 Poznań, Poland research. Specific nitrate reduction rate was estimated at $12.3 \mathrm{mg} \mathrm{N} \mathrm{g}^{-1} \mathrm{VSS} \mathrm{h}^{-1}$. Toxicity of wastewater samples during the denitrification process was studied by measuring the activity of dehydrogenases in the activated sludge. Mutagenicity was determined by employing the Ames test. The maximum mutagenic activity did not exceed 0.5 . The obtained results suggest that the studied wastewater samples did not exhibit mutagenic properties.

Keywords Biodegradation - Denitrification . Nitroglycerine $\cdot$ Nitroglycol $\cdot$ Toxicity test

\section{Introduction}

The removal of industrial waste with high nitrate content was considered as a major problem for waste purification technologies. This issue concerned mostly chemical plants, which produced nitrogen-based fertilizers (Leakowić et al. 2000; Zala et al. 2004) and water treatment plants, which produced brines after regeneration of ion exchange resin or after reverse osmosis processes (Cyplik et al. 2007; McAdam and Judd 2009). The production of plastics, nitric acid, or fuel additives has also contributed to the increase of nitrate level in wastewater. Particularly dangerous wastes were produced in explosives production plants (Christodoulatos et al. 1997). In recent years, after the opening of the Polish market, the Polish Defense Industry had to compete with producers from various 
countries. In Poland, many industrial plants changed their production profiles in the 1990s and began production for the civil market, focusing mainly on mining, petroleum (2-ethylhexyl nitrate used as an additive to increase the cetane number of diesel fuel) and plastics industry.

Wastewater from production of explosives possessed a very high concentration of nitrates and sulfates due to the usage of mixed nitrating acids. Another trait of the wastes from explosives production sites was a high number of organic compounds (nitroglycerin and nitroglycol among others), which was confirmed by high values of chemical oxygen demand (COD). Several studies revealed, that toxic or even mutagenic and carcinogenic organic compounds were present. In addition, they had specific, unbalanced composition: high concentration of nitrates, lack of phosphates and microelements, as well as the presence of hardly biodegradable organic compounds, which are a serious threat for the environment, and may disturb functioning of conventional waste treatment plants. Wastes produced in such plants were often combined into one stream flowing out of different production departments. Therefore, they were characterized by high diversity and nonhomogeneity in their composition.

The usage of membrane techniques for the treatment of waste from these industry plants was not possible because the sorption of nitroglycerin on such membranes causes a great risk of micro-explosions, which are dangerous for the membranes and may damage the whole installation. Other physicochemical methods, which were suggested but not used so far, are microwave-assisted degradation (Halasz et al. 2010) and reductive transformation by pyrite and magnetite (Oh et al. 2008).

An alternative and potentially more attractive way of waste treatment is the employment of biological methods. In the process of biological denitrification, nitrates are used by bacteria as a final electrons acceptor in the electron transport chain and are reduced to nitrogen. The addition of organic source of carbon and energy is required for denitrification process. Various xenobiotics, including nitroglycerin and nitroglycol, may be used as that source. Studies on nitroglycerin and nitroglycol biodegradation were conducted mainly under aerobic conditions using bacteria (Bhaumik et al. 1997; Ye et al. 2004; Dario et al. 2010), fungi (Sundaram et al. 1997), and plants
(Meagher 2000; Eapen et al. 2007; Rylott and Bruce 2008) thus far. Under anaerobic conditions, this process was carried out with the use of an anaerobic sludge (Christodoulatos et al. 1997). It should be highlighted that the possible employment of plants and fungi was limited for the removal of nitroglycerin and nitroglycol from soil. Moreover, these methods have not found application in waste treatment techniques because of a high nitrate level. Since nitrates acts as methane fermentation inhibitors, their presence limited the application of anaerobic sludge. Wastewater samples used in this study originated from an actual explosives production plant (their composition was not created artificially). Additionally, bacteria and activated sludge were not previously adapted to high nitrate concentrations and specific organic compounds' presence.

\section{Material and Methods}

\subsection{Characteristics of Wastes}

The nitrate processing wastewater was collected from Polish explosives production plant. No information regarding its detailed composition was obtained. The amount of wastes generated daily was at $240 \mathrm{~m}^{3}$. Wastes of many production departments are combined into one stream and flow into a drain collector. Because of their low $\mathrm{pH}(\mathrm{pH}=1.5)$, they are neutralized to $\mathrm{pH}=7.0$ by addition of lime. The determined composition of treated wastes was: N 3,000 $\mathrm{mg} \mathrm{l}^{-1}$, $21 \mathrm{mg}^{-1}$ chlorides, $1,880 \mathrm{mg}^{-1}$ sulfates. Moreover, the wastes contained organic compounds: $4.8 \mathrm{mg} \mathrm{l}^{-1}$ nitroglycol, $1.9 \mathrm{mg} \mathrm{l}^{-1}$ nitroglycerin, and a number of other unknown organic compounds (COD ranged from 1,200 to $4,000 \mathrm{mg} \mathrm{l}^{-1}$ ). This means that $720 \mathrm{~kg}$ day $^{-1}$ of nitrates, $2 \mathrm{~kg}$ day $^{-1}$ of nitroglycerin, and $0.5 \mathrm{~kg}$ day $^{-1}$ nitroglycol may be released to the environment.

\subsection{Microorganisms}

Bacterial consortium used throughout this study was isolated from petroleum-contaminated soil in the area of Carpathian Mountains, Poland and identified by restriction fragment length polymorphism of $16 \mathrm{~S}$ rRNA gene amplicons to consist of: Alcaligenes xylosoxidans, Citrobacter freundii, Comamonadaceae 
bacterium, Pseudomonas sp., Pseudomonas stutzeri, Sphingobacterium kitahiroshimense, Sphingobacterium $\mathrm{sp}$. The isolation procedure and genetic identification method were previously described by Owsianiak et al. (2009). Due to anaerobic cultivation it was given a unique name DNC2 which stands for DeNitrifying Consortium 2.

Activated sludge originating from a wastewater treatment plant $(52.449439 \mathrm{~N} 16.982890 \mathrm{E})$ in Koziegłowy near Poznań (Poland), was used in studies on wastewater denitrification. Additionally, it served as a comparative material for microorganisms used in these studies.

\subsection{Cultivation Conditions}

Two sets of experiments were carried out: one with the use of actual wastewater samples and another with synthetic wastewater. Due to the unbalanced composition of actual wastes, the following substances, required for denitrifying microorganisms' growth, were added prior to microbial processing $\left(\mathrm{g} \mathrm{l}^{-1}\right)$ : * $\mathrm{KH}_{2} \mathrm{PO}_{4} 2.8, \mathrm{NaCl} 0.5, \mathrm{NH}_{4} \mathrm{Cl} 1.0, \mathrm{MgSO}_{4} \cdot 7 \mathrm{H}_{2} \mathrm{O}$ $0.01, \mathrm{FeSO}_{4} \cdot 7 \mathrm{H}_{2} \mathrm{O} 0.001, \mathrm{MnSO}_{4} \cdot 4 \mathrm{H}_{2} \mathrm{O} 0.0005$, $\mathrm{ZnCl}_{2}$ 0.00064, $\mathrm{CaCl}_{2} \cdot 6 \mathrm{H}_{2} \mathrm{O} 0.0001, \mathrm{BaCl}_{2}$ 0.00006, $\mathrm{CoSO}_{4} \cdot 7 \mathrm{H}_{2} \mathrm{O} 0.000036, \mathrm{CuSO}_{4} \cdot 5 \mathrm{H}_{2} \mathrm{O} 0.000036$, $\mathrm{H}_{3} \mathrm{BO}_{3} 0.00065, \mathrm{H}_{2} \mathrm{MoO}_{4} \mathrm{0} 005$, EDTA 0.001 , $0.0146 \mathrm{ml} \mathrm{l}^{-1} \mathrm{HCl}(37 \%)$ and glycerol, a by-product of biodiesel production, was used as the external source of carbon $(\mathrm{C}: \mathrm{N}=4.0)$. The initial studies were performed with synthetic wastewater. It was composed of nitrate $\left(3 \mathrm{gN} \mathrm{L}^{-1}\right)$ and the substances mentioned before*. All experiments were carried out on a larger scale, in which microorganisms were cultured in a bioreactor (BioFlow 3, New Brunswick Scientific) with a working capacity of $5 \mathrm{~L}$. The culture conditions were set at $25^{\circ} \mathrm{C}$ and at a mixing rate of $100 \mathrm{rpm}$ and controlled automatically. The $\mathrm{pH}$ was automatically set to 7 or 9 by the addition of $5 \mathrm{M}$ $\mathrm{HCl}$ or $5 \mathrm{M} \mathrm{NaOH}$. Samples were collected every $24 \mathrm{~h}$. All the experiments were carried out in three replicates.

\subsection{Analytical Methods}

Nitrate determination of the brine was conducted with the aid of spectrophotometry $(\lambda=410 \mathrm{~nm})$ via the reaction with sodium salicylate. Nitrites were determined spectrophotometrically $(\lambda=520 \mathrm{~nm}$; Specord
40, Jena Analytic, Germany) through a reaction with sulfanilic acid and 1-naphthylamine as previously described by Cyplik et al. 2011. COD and volatile suspended solid (VSS) were determined using a standard method with dichromate described previously by Hermanowicz (1976). Nitroglycerine and nitroglycol were assayed by HPLC with a UV detector (HP Agilent 1050). A Lichrospher 100 RP-18 column (5 $\mu \mathrm{m}, 205 \times 4.6 \mathrm{~mm}$; Merck, Germany) was used.

\subsection{Dehydrogenase Activity Assay}

The amount of $0.3 \mathrm{ml}$ of a $2 \mathrm{gl}^{-1}$ solution of triphenyltetrazolium chloride was added into $1 \mathrm{ml}$ of sample containing activated sludge. The mixture was incubated at $25^{\circ} \mathrm{C}$ for $30 \mathrm{~min}$. Then, the samples were centrifuged for $3 \mathrm{~min}$. at $3,000 \times \mathrm{g}$ (HAERAUS, Germany). The centrifuged samples were extracted with $1.2 \mathrm{ml}$ of ethanol (95\%) and centrifuged again for $5 \mathrm{~min}$. at 3,000 $\mathrm{g}$. Extinction was measured using Specord 40 spectrophotometer at $490 \mathrm{~nm}$ (Jena Analytic, Germany). The activity of dehydrogenases was expressed as micromolar TF per gram VSS per minute ( $\mathrm{TF}$ - triphenyl formazan).

\subsection{Ames Test}

Mutagenic properties of wastewater samples were determined by the bacterial Ames test (Maron and Ames 1983) using three genetically modified strains of Salmonella typhimurium TA98, TA100 and TA1537, which originated from the Polish Collection of Microorganisms (Institute of Immunology and Experimental Therapy, PAS in Wrocław).

The reaction mixtures contained $100 \mu$ of bacterial suspension growing for $16 \mathrm{~h}$ in a liquid culture, $200 \mu \mathrm{l}$ of standard mutagen or the studied wastewater, and phosphate buffer to the total volume of $1 \mathrm{ml}$. The prepared reaction mixtures were preincubated at $37^{\circ} \mathrm{C}$ for $20 \mathrm{~min}$. Subsequently, they were added into surface agar, which contained trace amounts of histidine and biotin and were poured onto the surface of water agar supplemented with minerals and $10 \%$ glucose $[w / v]$. The dishes were incubated at $37^{\circ} \mathrm{C}$. After $48 \mathrm{~h}$ of cultivation, bacterial colonies were counted. The results were compared with control samples, i.e.: (1) negative, which was not supplemented with the mutagen, and (2) positive, containing the reference mutagen (2-aminofluorene for 
TA98 strain; sodium azide for TA100 strain, 2aminoacridine for TA1537 strain).

Based on the results, the mutagenic activity (AM) of each waste sample was calculated according to the following equation:

$\mathrm{AM}=\frac{R_{\mathrm{i}}-R_{\mathrm{S}}}{R_{\mathrm{S}}}$

where $R_{\mathrm{S}}$ is the number of revertants induced by the standard mutagen or studied waste; $R_{\mathrm{S}}$ is the number of spontaneous revertants in the negative control. If the AM value equals or is higher than two, the studied substance is mutagenic.

\section{Results and Discussion}

Wastewaters originating from chemical plants producing explosives are dangerous for the environment not only due to their high nitrate content, but also because of the presence of organic compounds with unknown compositions. Among them, nitroglycerin and nitroglycol are proven to be toxic for microorganisms (White and Claxton 2004).

\subsection{Initial Denitrification Studies with Model Wastewater}

Bacteria from activated sludge are the most frequently used microorganisms for waste treatment. Therefore, a mock trial was carried out to determine the application potential for microbiological denitrification of synthetic wastewaters during initial studies with activated sludge. Additionally, the soil deriving DNC2 consortium was incorporated into trial (Fig. 1). An important part of this step was to also divide the influence of toxic substances present in the actual wastewater from nitrates content, therefore the concentration of nitrates (3,000 $\left.\mathrm{mg} \mathrm{N}^{-1}\right)$ was the same as in wastes coming from plants producing explosive materials. It was observed that microorganisms from activated sludge as well as DNC2 consortium may be used for denitrification of industrial wastewaters. Complete removal of nitrates occurred after 2 days. Respiration activity of activated sludge and DNC2 was determined by measuring the activity of dehydrogenases. It proved to be a valuable method for monitoring processes' progress (Piotrowska-Cyplik et al. 2009; Chrzanowski et al. 2011). In a synthetic waste, which was free of any toxic substances, and constituted a study control, the activity of dehydrogenases was $4.79 \mu \mathrm{M} \mathrm{TF}^{-1} \mathrm{VSS} \mathrm{min}^{-1}$. An addition of nitrates, in the same amount as in the industrial wastewaters, did not cause a statistically significant decrease in the studied enzymes (dehydrogenase activity at $4.57 \mu \mathrm{M}$ TF $\mathrm{g}^{-1}$ VSS $\min ^{-1}$ ).

\subsection{Denitrification of Actual Wastewater Samples}

The unbalanced character of the wastes did not allow to simultaneously remove both organic compounds and nitrates. It was necessary to determine the optimum $\mathrm{C} / \mathrm{N}$ ratio, which in initial studies was 4 , similar to that reported by Fernández-Nava et al.
Fig. 1 Real and synthetic wastewaters denitrification by DNC2 consortium and activated sludge

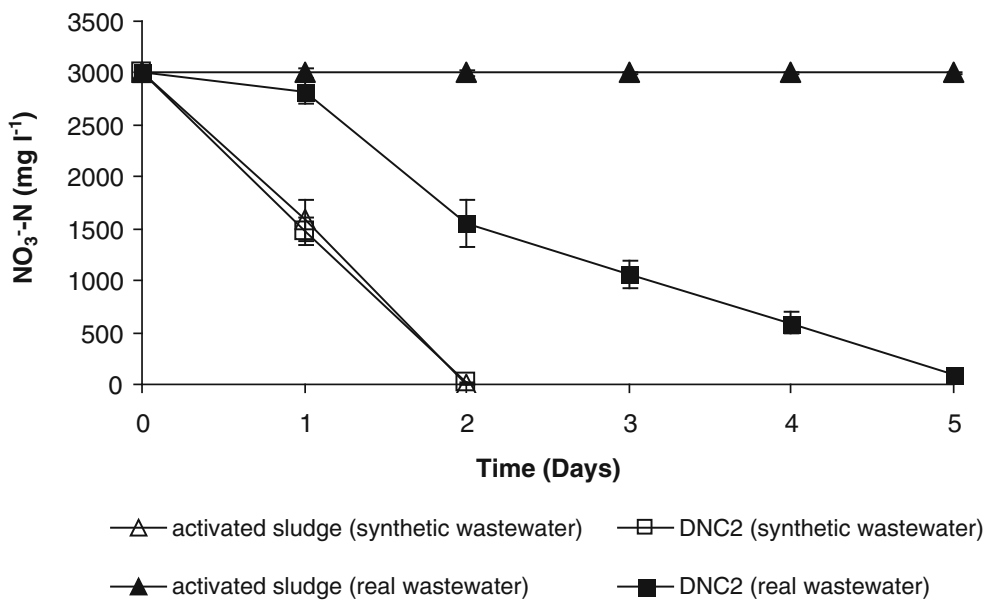


2008. At this step, glycerol was suggested as additional carbon source. Utilization of glycerol, a by-product of biodiesel production, in processes of industrial wastes denitrification may be one of the possibilities (da Silva et al. 2009).

Wastes were neutralized to $\mathrm{pH}=7.0$ by addition of calcium ions, which later were removed in a form of sediment.

Application of activated sludge and DNC2 consortium for denitrification of industrial wastewaters provided different results. The organic load of wastewaters had a toxic influence on activated sludge and inhibiting influence on DNC2 consortium which however proved to be resistant to organic substances present in wastes. The DNC2 consortium previously exhibited a significant biodegradation potential towards many organic compounds and high resistance against toxic xenobiotics in wastewaters, which may be an advantage during denitrification processes (Owsianiak et al. 2009). After an initial $24 \mathrm{~h} \mathrm{lag}$ phase, DNC2 consortium adapted to the environment and a complete denitrification occurred within 5 days. These results confirmed the previously calculated values of specific nitrate reduction rate for activated sludge and DNC2 consortium (Table 1). Calculation of zero order rate constant for nitrate removal $(k)$ confirmed these observations.

Therefore, it was decided that the denitrification processes of actual wastewater samples and wastewater without calcium ions should be run in two $\mathrm{pH}$ variants, at $\mathrm{pH}=7$ and 9 (Fig. 2).

By analyzing the obtained results and calculating zero order rate constant $(k)$ for nitrate removal for all cultures, a strong inhibiting impact of calcium ions on the denitrification process was observed (Table 2). Whereas in wastes from which calcium ions were removed, no significant differences were observed in the nitrates reduction rate for cultures processing at $\mathrm{pH}=7$ and 9. Their complete removal occurred after 5 days. Significant differences were observed in the concentration of forming nitrates during denitrification. At $\mathrm{pH}=9$, there was an accumulation of nitrates up to $1,840 \mathrm{mg} \mathrm{NO}-\mathrm{Nl}_{2}^{-1}$ on sixth day. On the same day, at $\mathrm{pH}=7$, nitrites were completely removed from wastes and their maximum concentration was recorded on the fourth day $\left(810 \mathrm{mg} \mathrm{NO}_{2}^{-}-\mathrm{NL}^{-1}\right)$.

Similar results were obtained by Fernández-Nava et al. (2008), who used activated sludge adapted to high concentrations of nitrates (from 0.5 to $1.0 \mathrm{~g}$ $\mathrm{NO}_{3}^{-}-\mathrm{Nl}^{-1}$ ) A complete removal of nitrates occurred after $6 \mathrm{~h}$ (denitrification rate, $22.8 \mathrm{mg}$ $\mathrm{NO}_{3}^{-}-\mathrm{Ng}^{-1} \mathrm{~h}^{-1}$ ), using methanol at $150 \mathrm{mg} \mathrm{L^{-1 }}$ calcium. Higher concentrations of calcium inhibited the denitrification process.

Contrary results were obtained by Dhamole et al. (2007) who denitrified wastes at $\mathrm{pH}=7.2$ with initial concentration of nitrates $9,000 \mathrm{mg} \mathrm{N} 1^{-1}$. They observed no inhibition of the process despite using a high concentration of nitrites $\left(6,000 \mathrm{mg} \mathrm{N}^{-1}\right)$. Glass and Silverstein (1997) conducted research regarding the influence of $\mathrm{pH}$ on the inhibition by nitrites of a denitrifying activated sludge and stated that high concentration of nitrites (more than 2,000 mg N 1${ }^{-1}$ ) did not influence the reduction process at $\mathrm{pH}$ 8.0. At $\mathrm{pH}=7.0$, the inhibition of the denitrification process with nitrates occurred after the addition of $250 \mathrm{mg}$ $\mathrm{NO}_{2}^{-}-\mathrm{Nl}^{-1}$, while at $\mathrm{pH}=6.0$ the inhibition occurred

Table 1 Specific nitrate reduction rate, removal efficiency of nitrate- $\mathrm{N}$ and reaction rate constant $(k)$ for the denitrification of real and synthetic wastewaters by activated sludge and DNC2 consortium

\begin{tabular}{|c|c|c|c|c|c|}
\hline \multirow[t]{2}{*}{ Parameters } & & \multicolumn{2}{|c|}{ DNC2 consortium } & \multicolumn{2}{|c|}{ Activated sludge } \\
\hline & & $\begin{array}{l}\text { Real } \\
\text { wastewater }\end{array}$ & $\begin{array}{l}\text { Synthetic } \\
\text { wastewater }\end{array}$ & $\begin{array}{l}\text { Real } \\
\text { wastewater }\end{array}$ & $\begin{array}{l}\text { Synthetic } \\
\text { wastewater }\end{array}$ \\
\hline Specific nitrate reduction rate & $\mathrm{mg} \mathrm{NO}_{3}^{-}-\mathrm{Ng}^{-1} \mathrm{VSS} \mathrm{h}^{-1}$ & 12.30 & 32.80 & 0.00 & 30.40 \\
\hline Removal efficiency of nitrate-N & $\%$ & 65.00 & 100.00 & 0.00 & 100.00 \\
\hline $\begin{array}{l}\text { Zero order rate constant for } \\
\text { nitrate removal }\end{array}$ & $\mathrm{NO}_{3}^{-}-\mathrm{Nl}^{-1} \mathrm{~h}^{-1}$ & 25.00 & 62.00 & 0.00 & 58.00 \\
\hline Finally biomass concentration & $\mathrm{g}^{-1}$ & $2.03 \pm 0.28$ & $1.95 \pm 0.34$ & $0.05 \pm 0.01$ & $2.05 \pm 0.17$ \\
\hline
\end{tabular}

Initial biomass concentration $=0.05 \pm 0.01 \mathrm{gl}^{-1}$ 
Fig. 2 Effect of $\mathrm{pH}$ and calcium ions on industrial wastewater denitrification

\section{A) $\mathrm{pH}=7, \mathrm{Ca}^{2+}$}

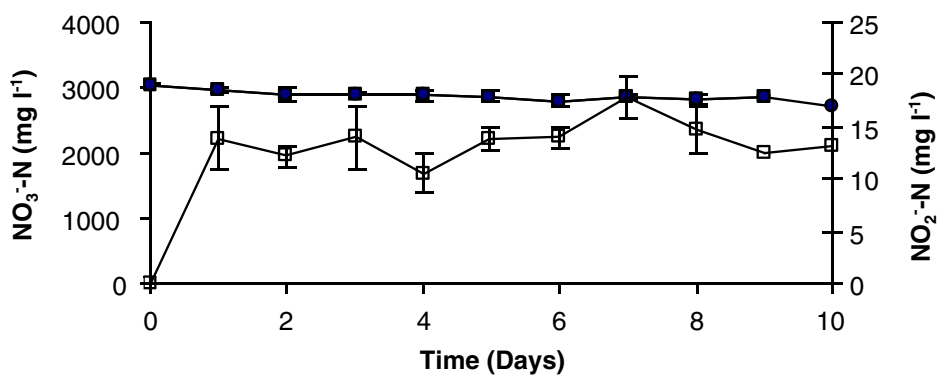

B) $\mathrm{pH}=9, \mathrm{Ca}^{2+}$

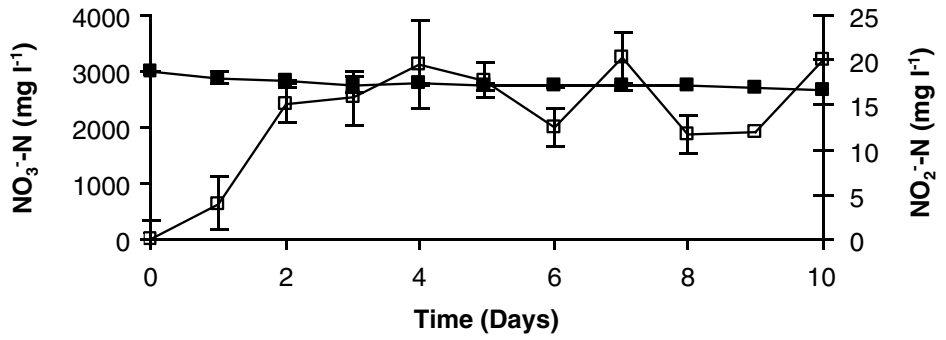

C) $\mathrm{pH}=9$, lack of $\mathrm{Ca}^{2+}$

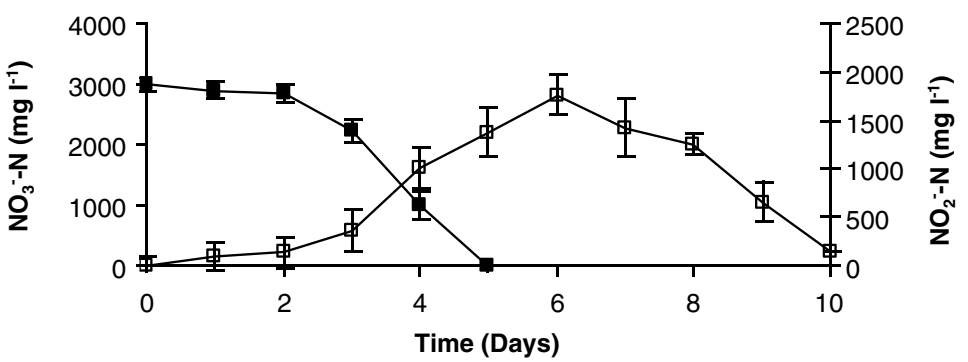

D) $\mathrm{pH}=7,0$, lack of $\mathrm{Ca}^{2+}$

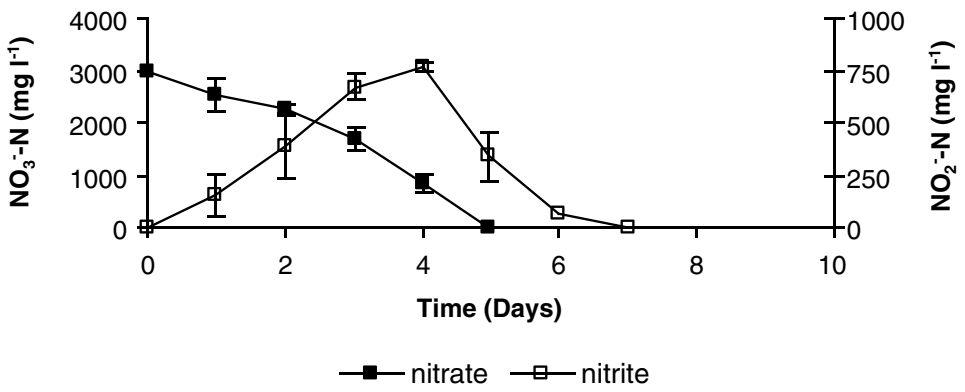

after the addition of $30 \mathrm{mg} \mathrm{NO}--\mathrm{Nl}^{-1}$. In addition, due to the inhibition risk connected with the use of calcium ions described by Fernández-Nava et al.
(2008), we studied the impact of calcium ions on the functioning of microorganism during the denitrification process. 
Table 2 Specific nitrate reduction rate, removal efficiency of nitrate-N and reaction rate constant $(\mathrm{k})$ for the denitrification of real wastewater

Parameters

DNC2 consortium

\begin{tabular}{lllll}
\hline $\mathrm{Ca}^{2+}$ & & & \multicolumn{2}{l}{ Lack of $\mathrm{Ca}^{2+}$} \\
\cline { 1 - 2 } $\mathrm{pH}=7$ & $\mathrm{pH}=9$ & $\mathrm{pH}=7$ & $\mathrm{pH}=9$ \\
\hline 0.00 & 0.00 & 12.30 & 12.00 \\
0.00 & 0.00 & 99.90 & 99.90 \\
0.00 & 0.00 & & 25.00 & 27.00 \\
0.00 & 0.00 & & 15.10 & 16.60 \\
0.00 & 0.00 & $2.05 \pm 0.26$ & $2.00 \pm 0.33$ \\
\hline
\end{tabular}

Initial biomass concentration $=0.05 \pm 0.01 \mathrm{gl}^{-1}$

\subsection{Removal of Organic Compounds \\ Followed by Denitrification}

In the first stage, the biodegradation of organic compounds under aerobic conditions at airflow of $51 \mathrm{~min}^{-1}$ was carried out (Fig. 3). It was observed that the DNC2 consortium was able to biodegrade organic compounds and after 7 days the COD value decreased from 22,000 to $124 \mathrm{mg} \mathrm{l}^{-1}$. A complete removal of nitroglycerin and nitroglycol occurred. No decrease in nitrates and nitrites concentration in wastewater samples was detected. Aeration was turned off after 7 days and microbiological removal of nitrates began. To obtain a complete denitrification, glycerol was added as an external source of carbon and energy. Nitrates were removed completely after 13 days. The experiment confirmed an inhibitory influence of organic compounds present in wastes on the
Fig. 3 Wastewater denitrification (a) and degradation of nitroglycerin and nitoglycol and dehydrogenase activity (b) during twophase aerobic-anaerobic treatment system

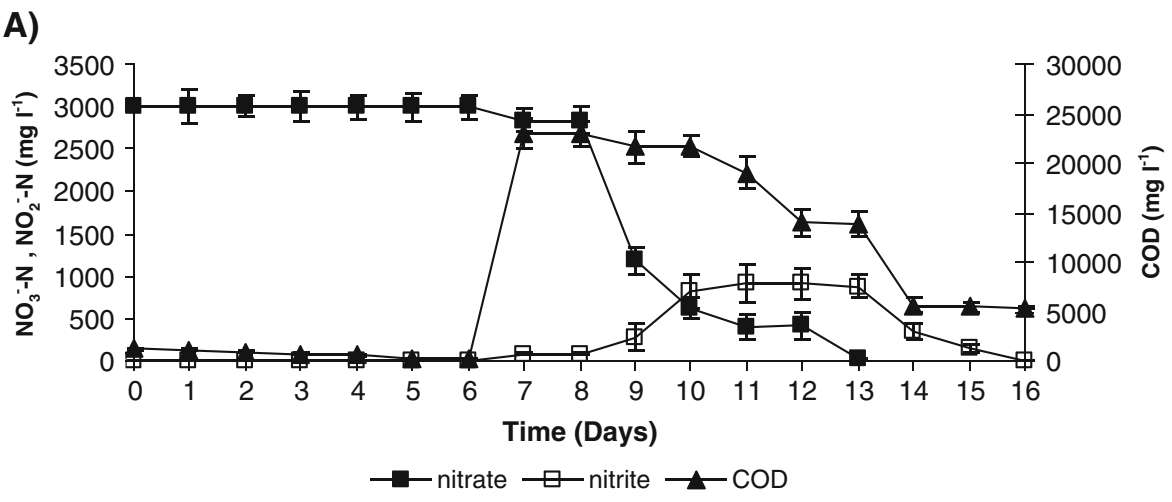

B)

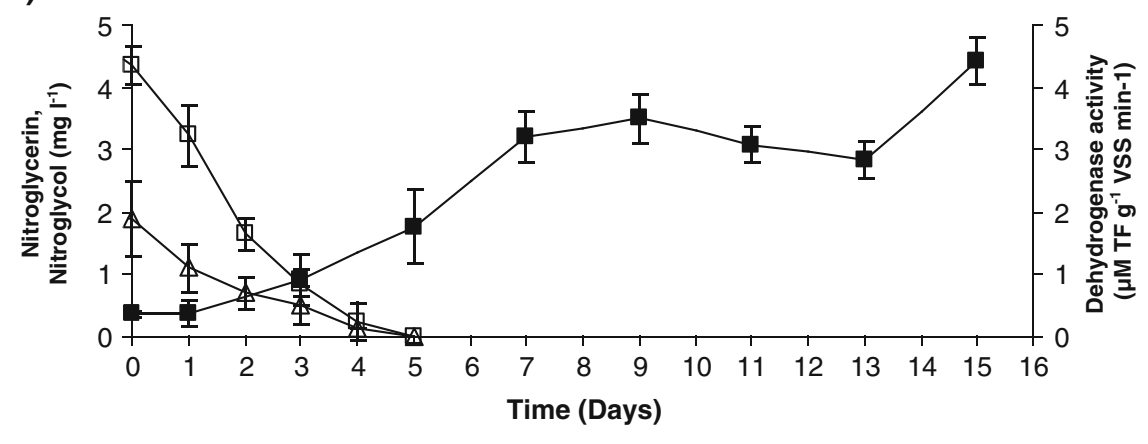

$\neg$ - dehydrogenase activity $\quad \triangle$ nitroglycol $\quad \square$ nitroglycerine 
denitrification process. A constant increase of nitrites content up to $910 \mathrm{mg} \mathrm{NO}-\mathrm{Nl}_{2}^{-1}$ was observed during the denitrification process until the day, when all nitrates were removed. Then, their concentration began to decrease, because in the absence of nitrates, the nitrites became the final electrons acceptor. During next 3 days, a complete removal of nitrites from wastes occurred (16 day).

\subsection{Denitrification Followed by Removal of Organic Compounds}

In this approach, the reduction of nitrates was performed as the first step of wastewater treatment (Fig. 4). Therefore, glycerol was added at the beginning of the process. Complete elimination of nitrates from the wastes was longer than in the first method, and occurred after 9 days. During this time an accumulation of nitrites with a maximum value of $770 \mathrm{mg} \mathrm{NO}-\mathrm{Nl}_{2}^{-1}$ on the fourth day was observed. A complete elimination of nitrites from wastes occurred during the subsequent 5 days with a constant reduction of nitroglycerin and nitroglycol. Nitroglycol was removed from the wastes on the eighth, and nitroglycerin on the ninth day of the process. During this time, the toxicity of the wastes decreased to the same extent as in the first experiment. Toxicity was measured by dehydrogenase activity in the active sludge. Glycerol supplementation did not influence nitroglycerin and nitroglycol biodegradation. Positive influence of extra supplemented carbon source was also reported by Bhaumik et al. (1997) and Dario et al. (2010) which used glucose for ethylene glycol dinitrate and nitroglycerin biodegradation.

\subsection{Toxic Effect of Wastewater}

It was observed that wastewater samples caused a significant drop in dehydrogenases activity after a direct contact with activated sludge. This finding confirmed their toxic character towards microorganisms present in the activated sludge. Raw wastes, and
Fig. 4 Wastewater denitrification (a) and degradation of nitroglycerin and nitoglycol and dehydrogenase activity (b) during anaerobic treatment system

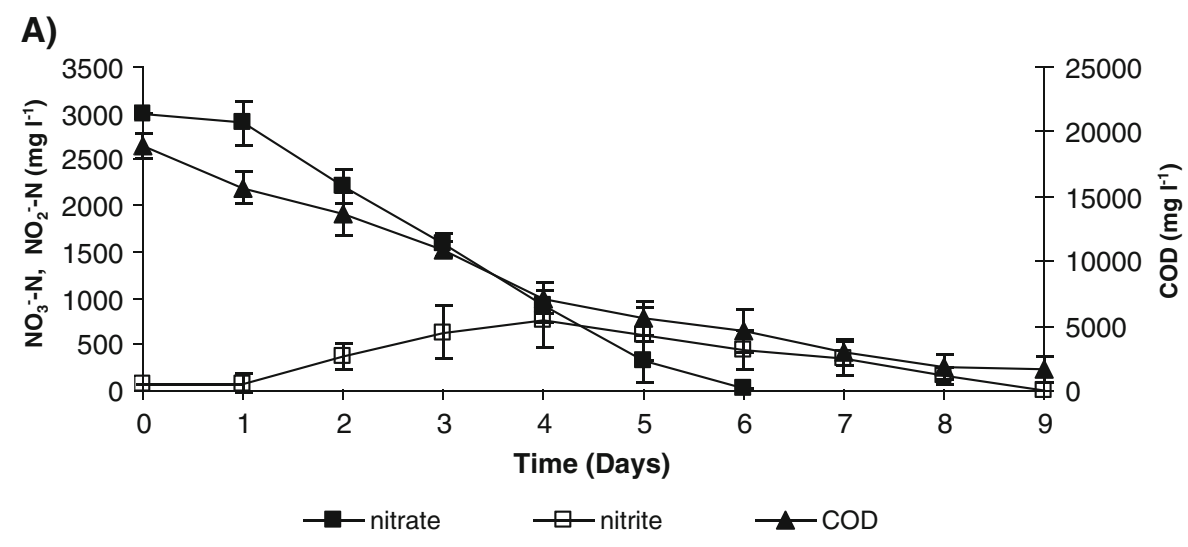

B)

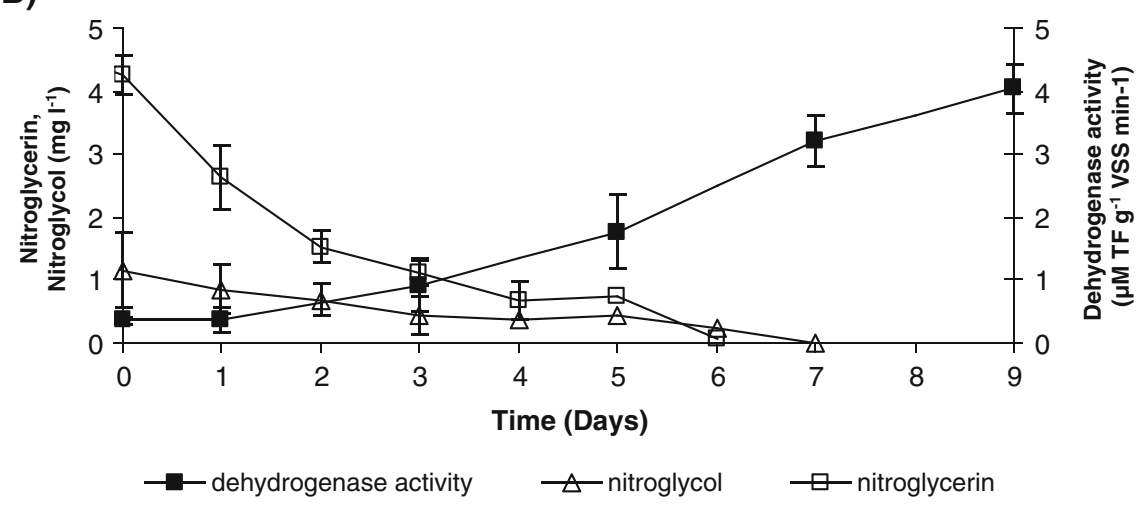


wastes devoid of calcium, thus containing nitrates and organic compounds, significantly inhibited the activity of dehydrogenases $\left(0.37 \mu \mathrm{M} \mathrm{TF} \mathrm{g}^{-1} \mathrm{VSS} \mathrm{min}^{-1}\right)$ and proved toxic for the activated sludge. Therefore, the toxicity of wastewaters was caused by the presence of organic compounds. Investigations on the activity of dehydrogenase in the activated sludge constituted a confirmation of wastes toxicity decrease. In the study, a high initial toxicity of wastes was confirmed (dehydrogenase activity, $0.39 \mu \mathrm{M}$ TF $\mathrm{g}^{-1}$ VSS $\min ^{-1}$ ). The toxicity decreased along with the degradation of organic compounds. A decrease in dehydrogenase activity on the thirteenth day of the process is worth mentioning. This drop was caused by an increase in nitrates concentration in wastewaters.

\subsection{Mutagenic Effect of Wastewater}

In order to determine the mutagenic properties of wastes, the Ames test was performed, which uses the mutation reverse effect in an altered Salmonella typhimurium strain, which was unable to synthesize one of the amino acids, histidine. Mutagenic properties of the investigated samples were determined based on a bacterial Ames test, using Salmonella typhimurium TA 100, TA98, and TA 1537 strains. The recognized mutagenic factors influence the bacterial genome, reverse the original mutation and recover the functioning gene coding for histidine and facilitate growth and colony formation on a medium with a slight addition of this amino acid. Use of different strains of Salmonella typhimurium, which posses various mutations in histidine operon genes, facilitates detection of a wide range of compounds, which damage DNA via different mechanisms. The used TA 100 strain is characterized by a substitution in hisG246 gene, while the mutation in TA 98 and TA 1538 strains is caused by frame shift in other genes of the histidine operon. An additional asset increasing the sensitivity of the test are the genetic changes, present in all Salmonella typhimurium strains, which reassure elevated sensitivity of the bacteria to mutagenic influence of the studied compounds. One of them is the mutation in $r f a$ gene, which results in a defect in lipopolysaccharide layer of the cell wall and makes it more permeable for the studied substances. Deletion in an $u v r B$ gene, which codes for enzymes removing pyrimidine dimers, decreases the ability to repair DNA damages via excision. The deletion also includes a bio gene, coding for biotin; therefore renders the bacterial growth dependent on biotin presence in the culturing medium. Introduction of a pKM101 plasmid to cells of TA100 and TA 98 strains enhances the chemical mutagenesis by increasing participation of the incorrect repair of DNA damages. In the performed test, the maximum amount of AM did not exceed 0.5 . Therefore, their toxicity did not have a mutagenic character (Table 3).

\section{Conclusions}

Based on the performed studies, it can be stated that selection of proper microorganisms DNC2 consortium, resistant to toxic xenobiotics present in wastewaters, is crucial for the removal of nitrates with a simultaneous nitroglycerin and nitroglycol elimination from wastewaters. Specific nitrate reduction rate was estimated at $12.3 \mathrm{mg} \mathrm{N} \mathrm{g}^{-1} \mathrm{VSS} \mathrm{h}^{-1}$. Gradual usage of organic compounds contained in wastes as a

Table 3 The number of colony and mutagenic activity (MA) of wastewaters at Ames test indicated

\begin{tabular}{|c|c|c|c|c|c|c|c|}
\hline \multirow[t]{2}{*}{$\begin{array}{l}\text { Salmonella } \\
\text { typhimurium } \\
\text { strains }\end{array}$} & \multirow[t]{2}{*}{$\begin{array}{l}\text { Spontanic revertants } \\
\text { (CFU/plate) }\end{array}$} & \multirow[t]{2}{*}{$\begin{array}{l}\text { Revertants induced by } \\
\text { mutagen }^{\mathrm{b}} \text { (CFU/plate) }\end{array}$} & \multirow[t]{2}{*}{$\begin{array}{l}\text { Mutagenic activity } \\
\text { for mutagen }\end{array}$} & \multicolumn{2}{|c|}{$\begin{array}{l}\text { Revertants induced } \\
\text { by waste water } \\
\text { (CFU/plate) }\end{array}$} & \multicolumn{2}{|c|}{$\begin{array}{l}\text { Mutagenic activity } \\
\text { of tested waste water }\end{array}$} \\
\hline & & & & $\mathrm{M}^{\mathrm{a}}$ & $\mathrm{M} 2^{\mathrm{b}}$ & $\mathrm{M}^{\mathrm{a}}$ & $\mathrm{M} 2^{\mathrm{b}}$ \\
\hline TA 98 & $12 \pm 4$ & $116 \pm 10$ & 8.67 & $16 \pm 11$ & $18 \pm 1$ & 0.33 & 0.50 \\
\hline TA 100 & $124 \pm 13$ & $397 \pm 13$ & 2.19 & $150 \pm 18$ & $158 \pm 24$ & 0.20 & 0.27 \\
\hline TA 1537 & $11 \pm 4$ & $1111 \pm 147$ & 97.00 & $5 \pm 1$ & $8 \pm 2$ & -0.53 & -0.29 \\
\hline
\end{tabular}

${ }^{\text {a }}$ Dose $340 \mu \mathrm{L}$

${ }^{\mathrm{b}}$ Dose $900 \mu \mathrm{L}$ 
carbon and energy source for denitrifying microorganisms allowed for the reduction of toxicity of the wastewaters. It was observed that initial activities of dehydrogenases $\left(0.39 \mu \mathrm{M}\right.$ TF $\left.\mathrm{g}^{-1} \mathrm{VSS} \mathrm{min}^{-1}\right)$ increase to $4.19 \mu \mathrm{M} \mathrm{TF} \mathrm{g}^{-1} \mathrm{VSS} \min ^{-1}$ at the end of wastewater treatment process. An Ames test was performed to determine the mutagenicity. The maximum mutagenic activity (AM) did not exceed 0.5 . Such results provide information that wastewater did not have a mutagenic character.

Acknowledgment Paweł Cyplik, Roman Marecik, and Łukasz Chrzanowski were financially supported by the Ministry of Science and Higher Education, Poland (Grant No. N N523 419837) years 2009-2012.

Open Access This article is distributed under the terms of the Creative Commons Attribution Noncommercial License which permits any noncommercial use, distribution, and reproduction in any medium, provided the original author(s) and source are credited.

\section{References}

Bhaumik, S., Christodoulatos, C., Korfiatis, G. P., \& Brodman, B. W. (1997). Aerobic and anaerobic biodegradation of nytroglycerin in batch and packed bed bioreactors. Water Science and Technology, 36, 139-146.

Christodoulatos, C., Bhaumik, S., \& Brodman, B. W. (1997). Anaerobic biodegradation of nitroglycerin. Water Research, 31, 1462-1470.

Chrzanowski, Ł., Owsianiak, M., Szulc, A., Marecik, R., Piotrowska-Cyplik, A., Olejnik-Schmid, A. K., et al. (2011). Interactions between rhamnolipid biosurfactants and toxic chlorinated phenols enhance biodegradation of a model hydrocarbon-rich effluent. International Biodeterioration and Biodegradation, 65, 605-611.

Cyplik, P., Grajek, W., Marecik, R., Króliczak, P., \& Dembczyński, R. (2007). The application of a membrane bioreactor to denitrification of brine. Desalination, 207, 134-143.

Cyplik, P., Schmidt, M., Szulc, A., Marecik, R., Lisiecki, P., Heipieper, H.J., et al. (2011). Relative-quantitative PCR to assess bacterial community dynamics during degradation of diesel and biodiesel fuels under various aeration conditions. Bioresource Technology, 102, 4347-4352.

da Silva, G. P., Mack, M., \& Contiero, J. (2009). Glycerol: a promising and abundant carbon source for industrial microbiology. Biotechnology Advances, 27, 30-39.

Dario, A., Schroeder, M., Nyanhongo, G. S., Englmayer, G., \& Guebitz, G. M. (2010). Development of a biodegradable ethylene glycol dinitrate-based explosive. Journal of Hazardous Materials, 176, 125-130.

Dhamole, P. B., Nair, R. R., D’Souza, S. F., \& Lele, S. S. (2007). Denitrification of high strength nitrate waste. Bioresource Technology, 98, 247-252.
Eapen, S., Singh, S., \& D'Souza, S. F. (2007). Advances in development of transgenic plants for remediation of xenobiotic pollutants. Biotechnology Advances, 25, 442-451.

Fernández-Nava, Y., Marańón, E., Soons, J., \& Castrillón, L. (2008). Denitrification of wastewater containing high nitrate and calcium concentrations. Bioresource Technology, 99, 7976-7981.

Glass, C., \& Silverstein, J. (1997). Denitrification kinetics of high nitrate concentration water: $\mathrm{pH}$ effect on inhibition and nitrite accumulation. Water Research, 32, 831-839.

Halasz, A., Thiboutot, S., Ampleman, G., \& Hawari, J. (2010). Microwave-assisted hydrolysis of nitroglycerin (NG) under mild alkaline conditions: New insight into the degradation pathway. Chemosphere, 79, 228-232.

Hermanowicz, W. (1976). Physicochemical testing of water and sewage. Poland: Arkady.

Leakowić, S., Mijatović, I., Serjan-Stefanović, S., \& Hodzić, E. (2000). Nitrogen removal from fertilizer wastewater by ion exchange. Water Research, 34, 185-190.

Maron, D. M., \& Ames, B. N. (1983). Revised methods for the Salmonella mutagenicity test. Mutation Research, 113, 173-215.

McAdam, E. J., \& Judd, S. J. (2009). Biological treatment of ion-exchange brine regenerant for re-use: A review. Separation and Purification Technology, 62, 264-272.

Meagher, R. B. (2000). Phytoremediation of toxic elemental and organic pollutants. Current Opinion in Plant Biology, 3, 153-162.

Oh, S.-Y., Chiu, P. C., \& Cha, D. K. (2008). Reductive transformation of 2,4,6-trinitrotoluene, hexahydro-1,3,5trinitro-1,3,5-triazine, and nitroglycerin by pyrite and magnetite. Journal of Hazardous Materials, 158, 652-655.

Owsianiak, M., Szulc, A., Chrzanowski, Ł., Cyplik, P., Bogacki, M., Olejnik-Schmidt, A. K., et al. (2009). Biodegradation and surfactant-mediated biodegradation of 1 diesel fuel by 218 microbial consortia is not correlated to cell surface hydrophobicity. Applied Microbiology and Biotechnology, 84, 545-553.

Piotrowska-Cyplik, A., Olejnik, A., Cyplik, A., Dach, J., \& Czarnecki, Z. (2009). The kinetics of nicotine degradation, enzyme activities and genotoxic potential in the characterization of tobacco waste composting. Bioresource Technology, 100, 5037-5044.

Rylott, E. L., \& Bruce, N. C. (2008). Plants disarm soil: engineering plants for the phytoremediation of explosives. Trends in Biotechnology, 27, 73-81.

Sundaram, S. T., Zhang, Y. Z., Sharma, A., \& Brodman, B. W. (1997). Screening for the involvement of the hydroxyl radical in the biodegradation of glyceryl trinitrate by Penicillium corylophilium Dierckz. Waste Management, 17, 437-441.

White, P. A., \& Claxton, L. D. (2004). Mutagens in contaminated soil: a review. Mutation Research, 567, 227-345.

Ye, J., Singh, A., \& Ward, O. P. (2004). Biodegradation of nitroaromatics and other nitrogen-containing xenobiotics. World Journal of Microbiology and Biotechnology, 20, 117-135.

Zala, S. L., Jayalexmy, A., \& Anjana, J. D. (2004). Nitrate removal from the effluent of a fertilizer industry using a bioreactor packed with immobilized cells of Pseudomonas stutzeri and Comamonas testosteroni. World Journal of Microbiology and Biotechnology, 20, 661-665. 